\author{
Tadeusz Bocheński \\ $\mathrm{dr}$ \\ Uniwersytet Szczeciński, Wydział Nauk o Ziemi, Katedra Badań Miast i Regionów \\ tadeusz.bochenski@usz.edu.pl
}

DOI: 10.35117/A_ENG_16_02_03

\title{
Passenger rail transport in Hungary
}

\begin{abstract}
The purpose of the article was to examine the passenger rail transport in Hungary. The scope of the research included transport on the public and generally accessible rail network. In the article there has been analyzed the size and structure of the passenger rail transport and their share in total transportation in the years 2001-2014. There was also examined the traffic volume of passenger trains running during weekdays in 2015. Hungary is a country where the rail has one of the largest shares in service of the passenger traffic in Europe. In the analyzed period, the railways transported in this country over 140 million passengers per year (it has to be remembered that the population of that country was less than 10 millions). Despite the popularity of this type of transport in the analyzed period the number of the passenger rail transport has been decreased.
\end{abstract}

Keywords: Rail; Hungary; Passenger transport

\section{Introduction}

Hungary is a country where rail has one of the largest shares in the handling of passenger traffic in Europe - lasting many years of over $10 \%$. The country has a well developed rail network and a functioning rail.

The aim of the article was to examine the operation of passenger rail transport in Hungary. The scope of the research took transports taking place on the public mainstream railway network. It analyzes the size and structure of passenger rail services and their share in total transportation in years 2001-2014. Examined traffic of passenger trains running on weekdays split into 3 categories (regional, higher-speed and express) in the timetable 2014/2015.

\section{Characteristics of the rail network}

The length of a public standard gauge railway network in Hungary was $7938 \mathrm{~km}$ and was managed by two entities: the state-owned Magyar Államvasutak Co. (MÁV), which held 97\% of the rail network and Sopron - Ebenfurt Vasutak Zrt. (GySEV), having less than 3\% of the rail networksj (table 1.). GySEV is an international company in which shares are held by the Hungarian state $(66.5 \%)$ and Austrian (28.6\%) and Austrian railways ÖBB AG (4,9\%). The company manages the rail network on the Hungarian-Austrian border of a total length $287 \mathrm{~km}$ [2].

Hungary has adopted the French model of vertical separation railway. Through the network between managers and railway undertakings and laying timetables dealt the established in 2004 state agency Vasúti Pályakapacitás-elosztó Kft. 
Tab. 1. Standard gauge widely available railway network in Hungary in 2010 [3].

\begin{tabular}{|c|c|c|c|c|c|c|c|c|c|c|}
\hline \multirow{3}{*}{ Zarządca } & \multirow{2}{*}{\multicolumn{2}{|c|}{ Ogółem }} & \multicolumn{4}{|c|}{ Niezelektryfikowane } & \multicolumn{4}{|c|}{ Zelektryfikowane } \\
\hline & & & \multicolumn{2}{|c|}{ jednotorowe } & \multicolumn{2}{|c|}{ dwutorowe } & \multicolumn{2}{|c|}{ jednotorowe } & \multicolumn{2}{|c|}{ dwutorowe } \\
\hline & $\begin{array}{l}\text { długośćć } \\
{[\mathrm{km}]}\end{array}$ & odsetek & $\begin{array}{l}\text { długośćc } \\
{[\mathrm{km}]}\end{array}$ & odsetek & $\begin{array}{l}\text { długośćć } \\
{[\mathrm{km}]}\end{array}$ & odsetek & $\begin{array}{l}\text { długość } \\
{[\mathrm{km}]}\end{array}$ & odsetek & $\begin{array}{l}\text { długośćć } \\
{[\mathrm{km}]}\end{array}$ & odsetek \\
\hline razem & 7938 & 100,0 & 5185 & 65,3 & 25 & 0,3 & 1511 & 19,0 & 1267 & 16,0 \\
\hline MÁV & 7727 & 97,3 & 5125 & 66,3 & 25 & 0,3 & 1360 & 17,6 & 1267 & 16,4 \\
\hline GySEV & 211 & 2,7 & 60 & 28,4 & 0 & 0,0 & 151 & 71,6 & 0 & 0,0 \\
\hline
\end{tabular}

Only $16 \%$ of the railway network in 2010 was double track. Electrified lines had power 25 $\mathrm{kV} 50 \mathrm{~Hz}$ and were $35 \%$ a public railway network (table 1., fig. 1.). Over $65 \%$ of the length of the railway network in Hungary were non-electrified monorail lines. The density of the railway network in 2010 was $7,9 \mathrm{~km} / 100 \mathrm{~km}^{2}$ [14].

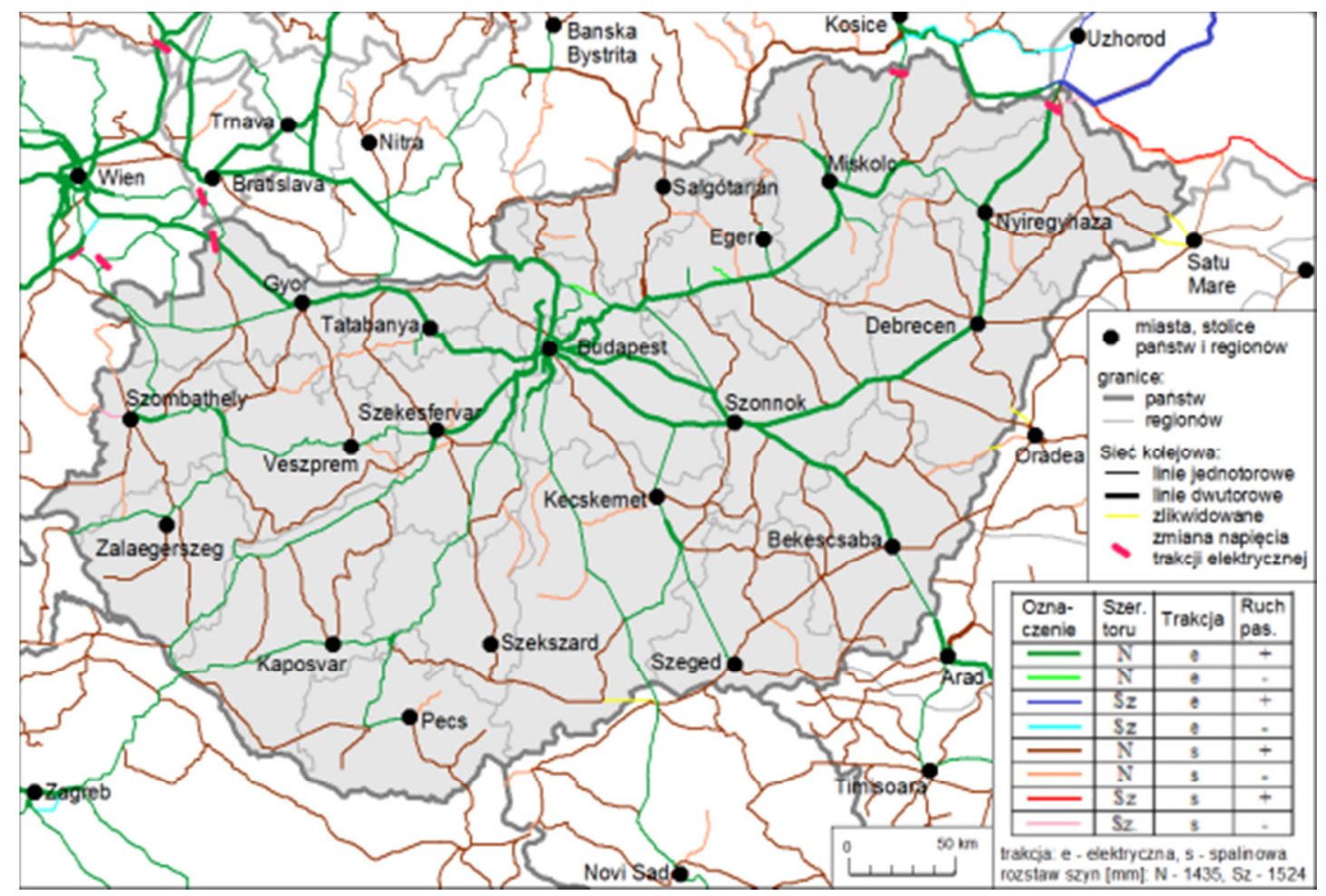

1. The railway network in Hungary in 2015 [10]

For 168 Hungarian counties (kistérség) Access to the active standard-gauge railway lines in 2010 had 166. In 2 counties: Mórahalom In the county Szeged and Letenye in county Szeksárd there was no active rail network. Over 5 counties: Mezőcsát in county Miskolc, Kalosa in county Keckemét, Polgar in county Debrecen, Pétervására in county Eger and Pécvárad in county Péc ran only railways with freight traffic [8]. Situation related to the availability of the railways since 2010 has not changed. The biggest cities deprived of railway passenger were: Békés in county Békéscsaba i Paks - a town in the county Szekszárd, both counted after less than 20 thousand residents. The first of them was located at the closed branching slip road from the main line connecting the Szolnok with Békéscsaba (nearest open station Murony was located $7.5 \mathrm{~km}$ west of the center of Békés). While the nearest open station around Paks was at a distance of $17 \mathrm{~km}$ west Nagydorog. In Paks, there is a nuclear power plant, and a ferry across the Danube. Therefore deprivation this facility of railway 
connections wonder. In addition, other railway lines leading to just across the Danube River town, including with more than 18 thousand residents of the city Kalocsa were also closed for passenger traffic (fig. 1.). Among the cities in the county without access to passenger trains were also a population of about 3 thousand. residents in the county Rétság Salgótarján and completely devoid of railways and with a population of about 2.5 thousand Pétervására residents in the county Eger.

The main transport hub of the country in which coincide all passing through Hungary international lines is Budapest. In the capital can be distinguished 4 main railway stations: Nyugati (Western), Keleti (Eastern), Déli (South) and Kelenföld. Only the last of these is the passage, while other stations are front stations. But the most important is Keleti.

Train stations were modernized in recent years, there are no such facilities like collisionfree handle to the platforms available for people with disabilities, and the same platforms are relatively low, making ingress and egress to / from high-floor depots are not the most convenient. However, at many stations there are parking lots for bicycles, often covered and their level of use evidenced by the popularity of rail travel in system bike \& ride.

\section{Railway passenger transport}

In the examined period, the railways transported in Hungary more than 140 million passengers a year. In years 2001-2010 was visible downward tendency in the number of transported passengers, but then increased again. In terms of transport work in 2005-2010 transports steadily dropped. The share of railways in public transport in terms of the number of passengers remained at the level of $21-22 \%$ only in 2008 fell slightly below $21 \%$. While in terms of transport performance fell, with only a small reflection in 2012-2013 (Table. 2). Taking into account the number of Hungarian population of nearly 10 million [1], the volume of traffic was considerable. For comparison, in 2014 volume of passenger transport in Poland (about 38 million) amounted to 268 million, and the transport performance 16 billion pkm [15].

Tab. 2. Passenger transport by rail in Hungary between 2001-2014 [1].

\begin{tabular}{|l|l|l|l|l|}
\hline \multirow{2}{*}{ Rok } & \multicolumn{3}{|l|}{ Wielkość przewozów kolejowych } & \multicolumn{2}{l}{$\begin{array}{l}\text { Udział kolei w przewozach } \\
\text { transportem zbiorowym }\end{array}$} \\
\cline { 2 - 5 } & $\begin{array}{l}\text { liczba } \\
\text { przewiezionych } \\
\text { pasażerów [mln] }\end{array}$ & $\begin{array}{l}\text { wykonana } \\
\text { praca } \\
\text { przewozowa } \\
\text { [mln pkm] }\end{array}$ & $\begin{array}{l}\text { liczba } \\
\text { przewiezionych } \\
\text { pasażerów [\%] }\end{array}$ & $\begin{array}{l}\text { wykonana } \\
\text { praca } \\
\text { przewozowa } \\
{[\%]}\end{array}$ \\
\hline 2001 & 161,7 & 10005 & 21,39 & 39,16 \\
\hline 2002 & 164,6 & 10531 & 21,78 & 40,35 \\
\hline 2003 & 159,9 & 10286 & 21,50 & 38,94 \\
\hline 2004 & 162,7 & 10544 & 22,07 & 38,74 \\
\hline 2005 & 156,4 & 9880 & 21,72 & 36,95 \\
\hline 2006 & 156,8 & 9584 & 21,73 & 34,56 \\
\hline 2007 & 149,8 & 8752 & 21,95 & 32,55 \\
\hline 2008 & 144,9 & 8293 & 20,97 & 31,91 \\
\hline 2009 & 142,8 & 8073 & 21,94 & 32,45 \\
\hline 2010 & 140,5 & 7692 & 21,53 & 30,70 \\
\hline 2011 & 145,7 & 7806 & 21,87 & 30,05 \\
\hline 2012 & 147,8 & 7806 & 22,08 & 33,52 \\
\hline 2013 & 148,5 & 7842 & 22,13 & 33,09 \\
\hline 2014 & 146,1 & 7738 & 21,75 & 30,88 \\
\hline
\end{tabular}


The share of rail-to-use of passenger transport via collective transport in Hungary remained high at over $20 \%$ in terms of number of passengers and more than $30 \%$ in terms of transport performance (Tab. 2). While most transport via collective transport in Hungary in the analyzed period was served by buses (over $70 \%$ of passengers and more than $40 \%$ the carried transport work).

Hungary belongs to the group of European countries with the largest share of railways in total passenger transport (including public and individual transport), next to Switzerland and Austria. This share has fallen in the last decade, however, all the time (except for 2010). Maintained at over $10 \%$ (tab. 3.).

Tab. 3. Share of rail in use of passenger transport overall in Hungary between 2001-2013 [6]. \begin{tabular}{|l|l|l|l|l|l|l|l|l|l|l|l|l|l|l|}
\hline Rok & 2000 & 2001 & 2002 & 2003 & 2004 & 2005 & 2006 & 2007 & 2008 & 2009 & 2010 & 2011 & 2012 & 2013 \\
\hline Odsen & 13,0 & 13,4 & 13,9 & 13,4 & 13,4 & 12,6 & 11,9 & 11,0 & 10,4 & 10,2 & 9,9 & 10,2 & 10,1 & 10,2 \\
\hline
\end{tabular} \begin{tabular}{|l|l|l|l|l|l|l|l|l|l|l|l|l|l|l|}
\hline Odsetek & 13,0 & 13,4 & 13,9 & 13,4 & 13,4 & 12,6 & 11,9 & 11,0 & 10,4 & 10,2 & 9,9 & 10,2 & 10,1 & 10,2 \\
\hline
\end{tabular}

\section{Passenger rail connections in Hungary}

In railway transport in Hungary, taking into account the price for the transfer and the number of stations where stop different trains can be distinguished four categories of trains: agglomeration (HÉV), regional (SR - Suburban IR - Interregional) fast trains (P - long distance) and express (IC, EC, Ex, EN, RJ). In this elaboration, the analysis of the rail omitted trains agglomeration not included in the timetable published by MÁV Start. They ran only after a separate railway network Budapesti Helyiérdekü Vasút (HÉV), administered by Budapesti Közlekedési Vállalat (Budapest International Transport Company) supporting public transport in the agglomeration of the capital.

Most regional connections functioned nearby the Budapest, including the surrounded regional centers (capitals of counties): Tatabánya, Székesfehérvár and Szolnok.More than 20 pairs of regional trains ran also between Miscolc and Nyiregyháza. and more than 15 between Szolnok and Debrecen, Eger and Miscolc, Szeged and Békéscsaba and around Szombathely (Fig.2.).

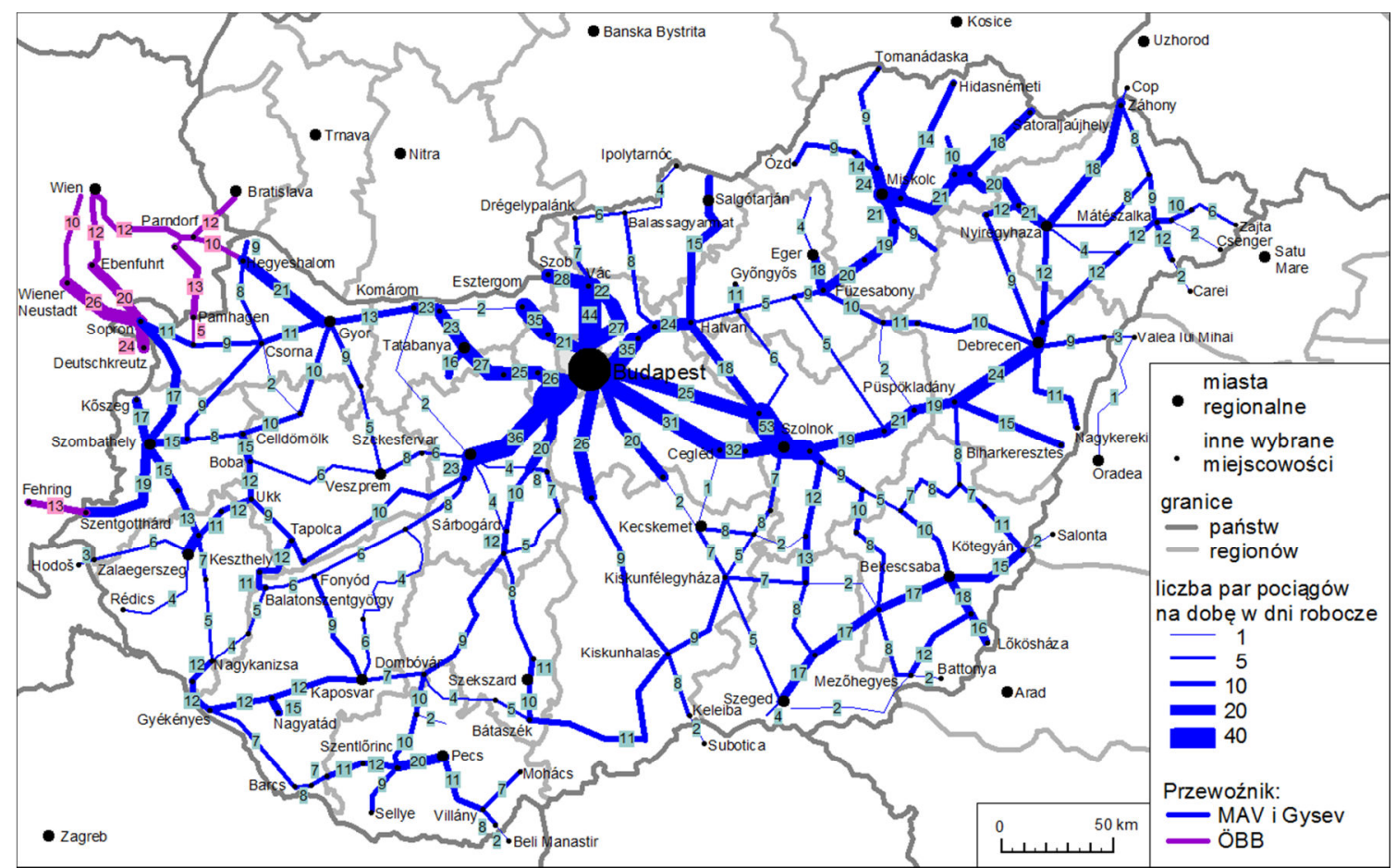

2. The traffic volume of regional trains in Hungary in 2015 out of summer season [11], [12] 
A separate group of regional connections were cross-border connections. Most trains ran cross the border with Austria and all of them were supported by the Austrian railways ÖBB (Fig. 2.). Beyond this total 7 pairs of trains ran by the Romanian border, exceeding it in 3 places, 3 through Slovenian and 2 by the Serbian and Croatian. Whereas between Slovakia and Hungary did not run even a single bordertrain, only express international trains (Fig.4.).

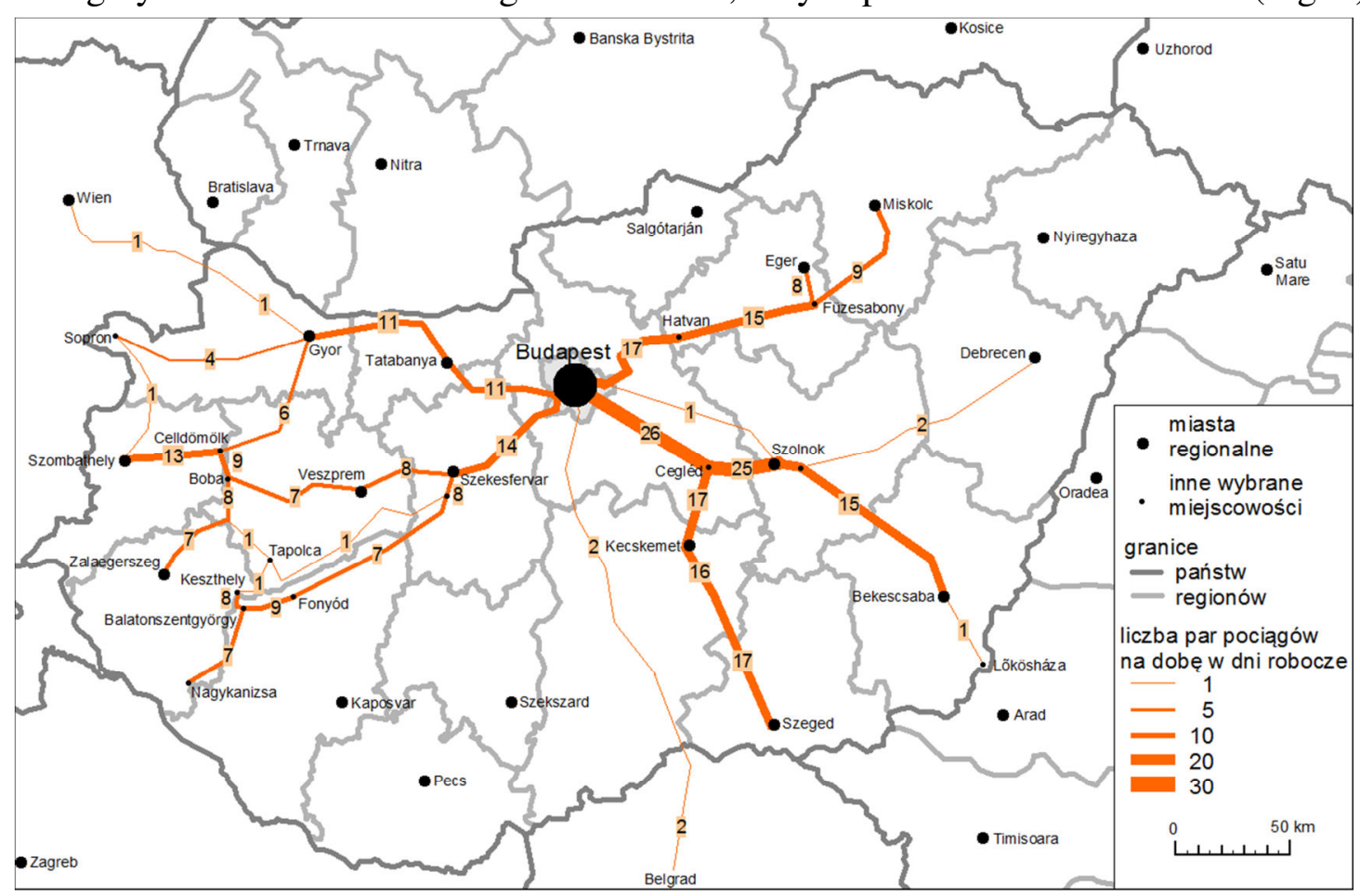

3. The intensity of fast trains traffic in Hungary in 2015 out of summer season [11]

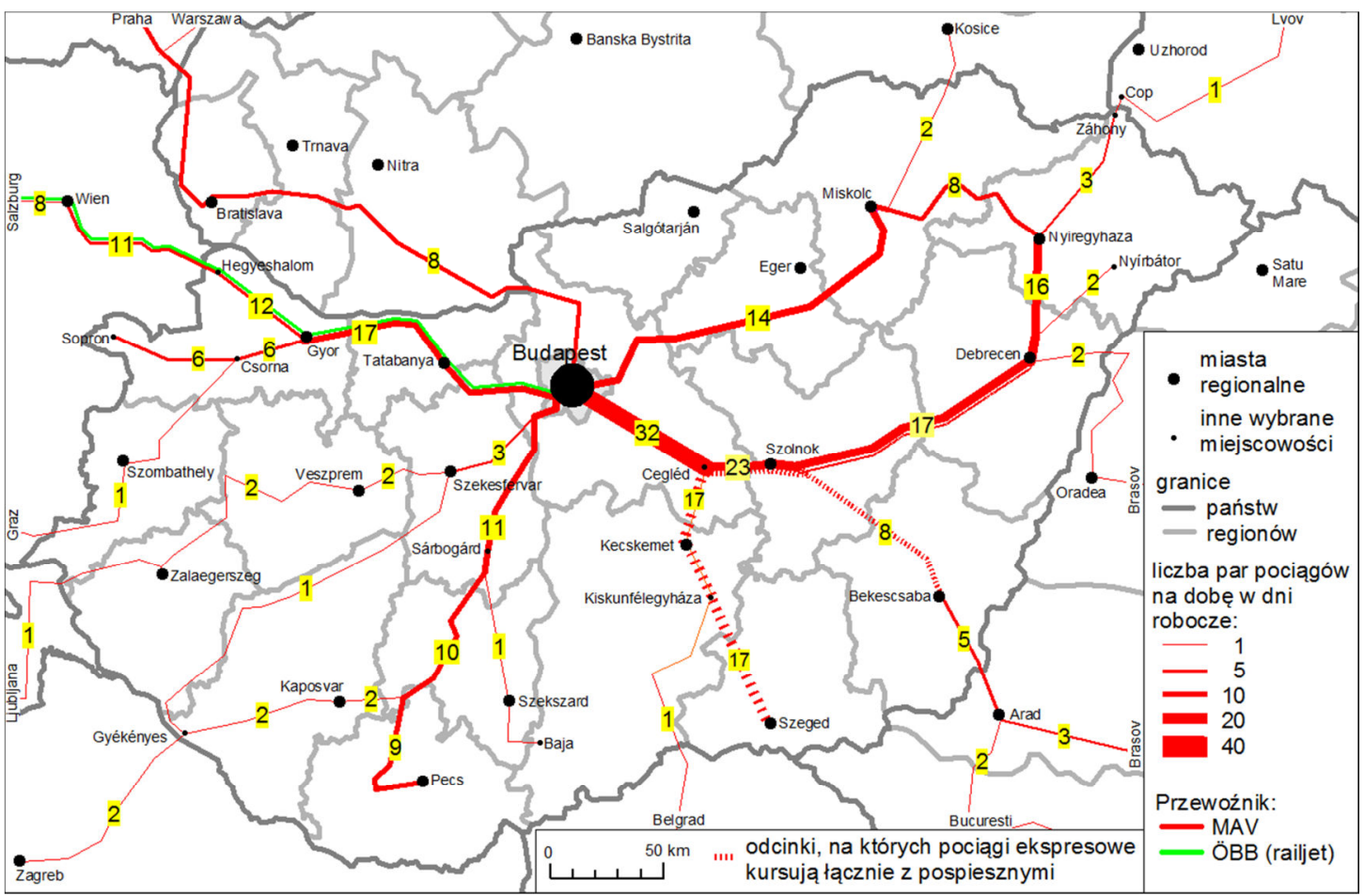

4. The traffic volume of express trains in Hungary in 2015 out of summer season [11]

Almost all regional centers (which are the capitals of the county), with the exception of Salgótarján (Table 4.). had qualified long-distance connections and direct links with the 
capital. Among other this kind of centers only Eger had no express connections, only fast trains, while four others (Kaposvár, Pécs, Szekszárd and Nyiregyháza) had only express connections (Fig. 3 i 4).

On some sections (Cegléd - Kecskemét - Szeged, Szolnok-Békéscsaba and Szolnok Debrecen) some part of trains ran at the same time as fast trains and express (Fig. 4.).

Tab. 4. The number of direct railway from the capital to regional cities in Hungary in [11]

\begin{tabular}{|l|l|l|l|l|l|l|}
\hline \multirow{2}{*}{ Miasto } & \multirow{2}{*}{$\begin{array}{l}\text { Odległość } \\
{[\mathrm{km}]}\end{array}$} & $\begin{array}{l}\text { Czas } \\
\text { przejazdu } \\
{[\text { min.] }}\end{array}$ & Regionalne & Pospieszne & Ekspresowe & razem \\
\cline { 5 - 7 } & & $33-44$ & 25 & 11 & 17 & 53 \\
\hline Tatabánya & 60 & $38-57$ & 45 & 14 & 3 & 62 \\
\hline Székesfehérvár & 63 & $74-101$ & 36 & 25 & 16 & 77 \\
\hline Szolnok & 100 & $77-123$ & 1 & 16 & 1 & 18 \\
\hline Kecskemét & 106 & 127 & 0 & 2 & 1 & 3 \\
\hline Veszprém & 108 & $184 * *$ & $(13)^{* *}$ & 0 & 0 & $(13)^{* *}$ \\
\hline Salgótarján & 126 & $66-115$ & 8 & 11 & 17 & 36 \\
\hline Győr & 127 & 129 & 0 & 8 & 0 & 8 \\
\hline Eger & 140 & 165 & 0 & 0 & 1 & 1 \\
\hline Szekszárd & 149 & 123 & 0 & 9 & 14 & 23 \\
\hline Miskolc & 182 & 160 & 0 & 0 & 1 & 1 \\
\hline Kaposvár & 191 & $142-195$ & 1 & 16 & $(17)^{*}$ & 17 \\
\hline Szeged & 191 & 149 & 0 & 15 & $(8)^{*}$ & 15 \\
\hline Békéscsaba & 196 & $171-204$ & 1 & 9 & 17 & 27 \\
\hline Debrecen & 221 & 176 & 0 & 0 & 9 & 9 \\
\hline Pécs & 228 & $158 / 220 / 235$ & $0 / 0 / 0$ & $0 / 1 / 6$ & $5 / 0 / 0$ & 12 \\
\hline Szombathely & $230 / 232 / 244$ & 229 & 0 & 6 & 1 & 7 \\
\hline Zalaegerszeg & 239 & $178-248$ & 1 & 7 & 20 & 28 \\
\hline Nyíregyháza & 270 & & & & \\
\hline
\end{tabular}

* Express trains run on part of the route as fast and regional trains,

** only connections with change in Hatvan (time for a change was 23 minutes).

All long-distance connections passed or started in the capital of Hungary. Except the interconnections, Budapest was also a major hub for international rail connections (Fig. 5.). International network was operated in most express trains. It included, among others, direct connections to all the capitals of neighbouring countries, as well as the Czech Republic, Germany, Switzerland, Bulgaria and Poland (Fig. 5). For several of these connections were only operated on the principle of direct carriages attached to the intermediate stations for trains other relations (to Warsaw in Breclav in the Czech Republic to the train station IC Vienna - Warsaw to Kiev Chop Ukraine to train UZ Chop - Kiev and Sofia in Curtici in Romania to train CFR / BDZ Curtici - Sofia).

A significant number of cross-border connections and international supported regional trains ÖBB had Sopron. From the city that can be reached, among others, Vienna - 22 connections (two routes) and to Bratislava via Vienna - 12 connections (Fig. 2).Between Austria and Hungary ran in total 73 pairs of trains, including 13 long-distance. Such a large number of connections resulted from the large role of the railways in freight handling in both countries and the mutual economic links, including commuting, e.g. on the route Sopron Vienna. Altogether 14 pairs of trains, including 7 long-distance united Hungary with Romania. The situation was different at the Hungarian-Slovakian border, where ran 10 pairs of trains, but only long distance (Fig. 5). At the beginning of the second decade of the twentyfirst century Slovak railways closed down local cross-border connections with Hungary. At 
railway communication between these countries probably affected a large Hungarian minority, which Romania had almost 1.5 million people, and in Slovakia, approximately 0.5 million [4]. In addition, Romania, and especially the top of this country were frequent direction of leisure Hungarans trips [9]. In addition, 9 pairs of trains united Hungary with Germany, and 7 pairs arrived to the Czech Republic. This was due to railway popularity in these countries and economic links. Serbia and Hungary were connected with 5 pairs of trains a day, including 3 long-distance. Similarly, to the Ukraine ran 5 pairs of trains including one long distance. Difficulty in these relations were crossing the external border of the European Union, and also very high ticket prices to the Ukraine. To Croatia and Slovenia ran in total 4 pairs of trains. In these countries, the railway was relatively underdeveloped and not very popular, which probably had a significant impact on the number of connections.

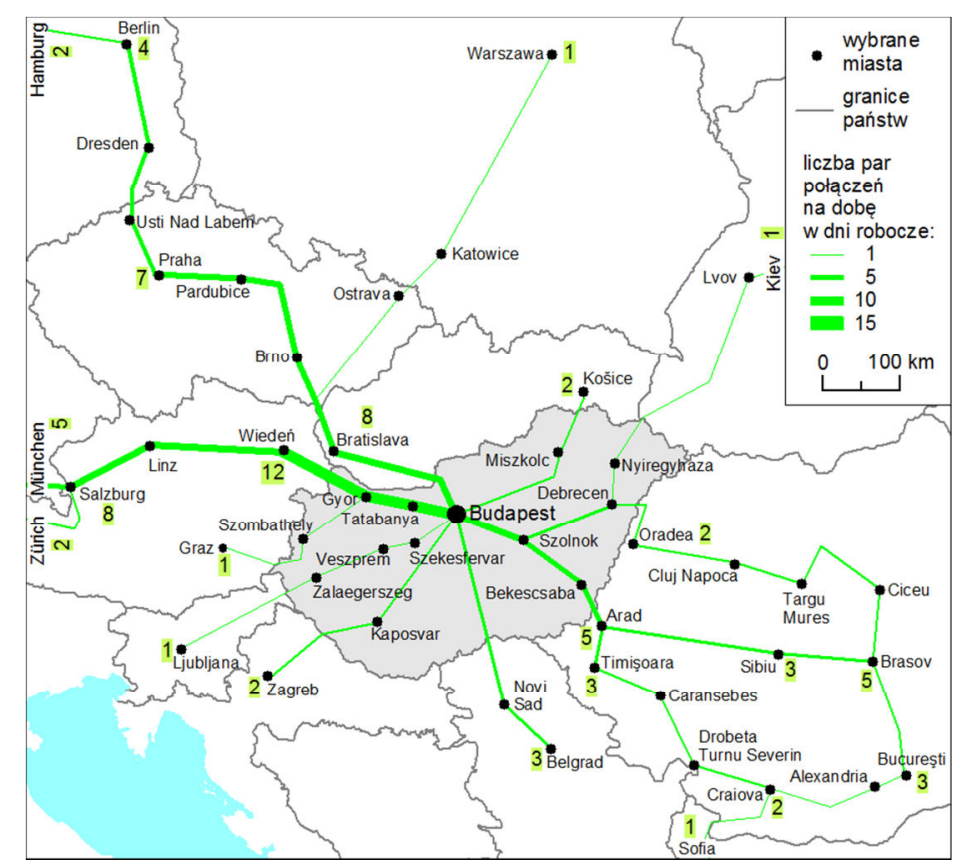

5. International direct rail connections from Budapest in 2015 out of summer season [16]

Timetable of the Hungarian railway was created for most of the connections in the tact system, which means that trains on the routes ran at regular intervals.

Most of connections were serviced by carriage depots, often in the Push-Pull system, so there was no need for shunting locomotives in case of change the direction of travel. Whereas local connections in large part were serviced by small PCS. Only recently they purchased new rolling stock, including Flirt EMUs type [7], and in Pusztaszabolcs it was established a service center for this rolling stock [13]. Therefore, the participation of this type of rolling stock is systematically increasing. National passenger carrier MÁV Start besides EMU also has invested in new carriages and locomotives for trains IC category. The rolling stock investments were realized with financial support from the European Union funds.

\section{Summary}

Hungarian railways do not belong to the most modern, nor the fastest, but are very popular. The railway network is relatively dense and most cities have access to the railway with passenger traffic. Quite incomprehensible is however deprivation Paks of this access. In Hungary, the share of rail passenger transport is one of the highest in Europe, as well as in neighboring Austria. This fact, together with the operation of the Austro-Hungarian railway company GySEV affects the well-connected railway between the two countries. Very important is also a shipping offer, including a significant number of of connections and tact 
timetable. In terms of number of passengers rail in Hungary in the last decade, however, it recorded a decline in the volume of long-distance transport and regional authorities, which are the subject of this analysis.

Characteristic is relatively good connection of Hungary in international relations, especially with Austria, Romania and Germany. Large traffic of trains in international relations was conditioned, inter alia, by popular railways in neighboring countries, affordable tariff carrier and the size of the economic links. The decrease in the role of railway can be explained by delaying modernization of infrastructure and replacement of rolling stock and still developing network of motorways and expressways.

\section{Source materials}

[1] Dane węgierskiego urzędu statystycznego (https://www.ksh.hu)

[2] DIOMIS. Evolution of intermodal rail/road traffic in Central and Eatern Euroean Countries by 2020. Hungary, 2009, UIC, s. 8.

[3] DIOMIS. Evolution of intermodal rail/road traffic in Central and Eatern Euroean Countries by 2020. Hungary, 2009, UIC, 31 oraz Magyaroszág vasútbarát térképe, 2010, ALAPPONT.

[4] Encyklopedia PWN (http://encyklopedia.pwn.pl)

[5] Eurostat (http://appsso.eurostat.ec.europa.eu)

[6] Eurostat (http://appsso.eurostat.ec.europa.eu)

[7] Koleje Węgierskie uzupełniają tabor, Euroinfrastruktura.pl, 12.11.2014 (http://www.euroinfrastructure.eu)

[8] Magyaroszág vasútbarát térképe, 2010, ALAPPONT

[9] obserwacje z podróży do Rumuni w latach 2010-2015

[10] Portal z mapami sieci kolejowych krajów Europejskich (http://www.bueker.net - dostęp 05.2012)

[11] Rozkład jazdy kolei węgierskich (http://www.mavcsoport.hu)

[12] Rozkład jazdy kolei austriackich (https://ticketing.oebb.at)

[13] Stadler Rail (http://www.stadlerrail.pl)

[14] Statystyka Międzynarodowa, GUS (http://stat.gov.pl)

[15] Transport. Wyniki działalności, GUS, 2014 